\title{
IN VITRO ANTIBACTERIAL ACTIVITY OF MEDICINAL PLANTS IN THE CENTRAL NORTH OF MOROCCO: A POSSIBLE SOURCE OF ALTERNATIVE DRUGS AGAINST METHICILLIN-RESISTANT STAPHYLOCOCCUS AUREUS
}

\author{
IKRAME ZEOUK ${ }^{1}$, ABDELHAKIM EL OUALI LALAMI ${ }^{2,3}$, KHADIJA BEKHTI $^{1 *}$ \\ ${ }^{1}$ Department of Biology, Sidi Mohamed Ben Abdellah University, Faculty of Sciences and Techniques, Laboratory of Microbial \\ Biotechnology, PB 2202, Fez, Morocco. ${ }^{2}$ El Ghassani Hospital, Regional Health Directorate, Institute of Nursing Professions and Health \\ Techniques Fez (Annex Meknès), 30000 Fez, Morocco. ${ }^{3}$ El Ghassani Hospital, Regional Health Directorate, Regional Diagnostic Laboratory \\ of Epidemiological and Environmental Health, 30000 Fez, Morocco. Email: bekhti.bki4@gmail.com
}

Received: 14 December 2018, Revised and Accepted: 20 November 2018

ABSTRACT

Objective: The present study aims the investigation of the antimicrobial potential of medicinal plants selected in the central north of Morocco against methicillin-resistant Staphylococcus aureus and Staphylococcus epidermidis strain often involved in dermatitis.

Methods: Structured interviews were carried out among 91 herbalists and traditional healers through a specific information questionnaire, the in vitro susceptibility of Staphylococcus strains award ethanol extracts was evaluated using the well-diffusion assay, while the agar-microdilution method was used to determinate the minimal inhibitory concentrations (MIC). The total phenolic and flavonoids contents of all tested extracts were also determined.

Results: Based on the ethnobotanical survey, a total of 55 plant species belonging to 30 families were mentioned. The Lamiaceae family was the most represented (18.80\%) followed by the Apiaceae family (10.90\%). Leaves (45.00\%) were the favored used part. Decoction method (48.53\%) was the most frequently used to prepare remedies that are taken externally (75.00\%). Nine of the 17 most selected species have shown an effective antistaphylococcal activity; the most active extracts were Punica granatum and Rhamnus alaternus with MIC values ranging between $0.25 \mathrm{mg} / \mathrm{ml}$ and $2.00 \mathrm{mg} / \mathrm{ml}$

Conclusion: The current data confirm the good antistaphylococcal activity of P. granatum and $R$. alaternus and suggest that these species could constitute a promoter source for antistaphylococcal drugs with deeply studies.

Keywords: Ethnobotanical study, Morocco, Plant extracts, Antistaphylococcal activity, Phytochemical assay

(c) 2019 The Authors. Published by Innovare Academic Sciences Pvt Ltd. This is an open access article under the CC BY license (http://creativecommons. org/licenses/by/4. 0/) DOI: http://dx.doi.org/10.22159/ajpcr.2019.v12i3.30395

\section{INTRODUCTION}

Staphylococcus species are opportunistic bacteria and the most pathogenic species. Strains of Staphylococcus aureus are able to colonize all tissues [1], secrete various enzymes and toxins [2-4] and cause various diseases including skin infections $[5,6]$. Microbial infections are normally treated using antibiotics, but the development of resistant strains award current antibiotics has become increasingly common which constitutes a growing public health problem, especially since these multi-resistant strains are no longer confined to hospital environments but are also found in the community $[7,8]$. Moreover, the emergence of strains of $S$. aureus resistant to methicillin (MRSA) makes the bacterium very dangerous and put a therapeutic problem. This resistance has stepped up the use of vancomycin, main antibiotic used to fight the MRSA infections; in 2002 a study showed that some strains of MRSA were also resistant to vancomycin (RVSA) [9]. The multi-resistance is serious; significant efforts must be invested to search new effective anti-MRSA bioactive molecules. Given that $75 \%$ of the drugs against infectious diseases are natural products or natural derivatives [10], herbal medications are more used, and a large number of plants possess antimicrobial activity [11-13]. In this context, we target the region of Fez-Meknes located in the center of Morocco known by its particular geographical situation very rich in biodiversity to select anti skin infections medicinal plants and to evaluate theirs in vitro actions against Staphylococcus strains and especially MRSA. The primary objective of the current study was to aid the progressive scientific works related to the antimicrobial activity of plants.

\section{METHODS}

Study area

Located in the central North of Morocco (Fig. 1), partially integrating the plain of Saïss and along siding the mountain ranges of the Rif and the Middle Atlas, Fez-Meknes region covers an area of $40.075 \mathrm{~km}^{2}$ corresponding to $5.7 \%$ of the national territory [14]. This region regroups the Prefectures of Fez and Meknes and the provinces of Boulemane, El Hajeb, Ifrane, Moulay Yaâcoub, Sefrou, Taounate and Taza [14].

The region of Fez-Meknes has 4.236.892 inhabitants [15], the density is 105.7 inhabitants per $\mathrm{km}^{2}$, very high compared to the national average (47.6 hab $\left./ \mathrm{km}^{2}\right)$. Due to its particular strategic position, the region is characterized by three climatic types; (i) a continental climate in the northern part, very hot and very dry in summer and cold and wet in winter. The winds are dry and cold or cold and wet in winter and hot in summer (Chergui), (ii) a cold and humid climate in a mountainous area, very cold and very snowy in winter and temperate in summer, and (iii) a semi-arid climate in the high hills of Boulemane. Winters are very cold and snowy [14]. The current study was undertaken in the prefectures of Fez and Meknes that are most populated (1,150,131 and 835,695 inhabitants, respectively) [15] and the province of Taounate that $90 \%$ of its communes are rural [16], the local population of this province resorts commonly to herbal medicine. 
Ethnobotanical survey

Skin infections such as Impetigo or Furunculosis (Fig. 2) are specific infections caused by $S$. aureus, for this reason, they were the basis of a questionnaire among herbalists. The survey was carried out during the year 2017. In addition to personal sociodemographic data of the interviewers, the questionnaire has also included information about the recommended plants, vernacular names, used parts, preparation, and administration mode. In general, the most recommended plants

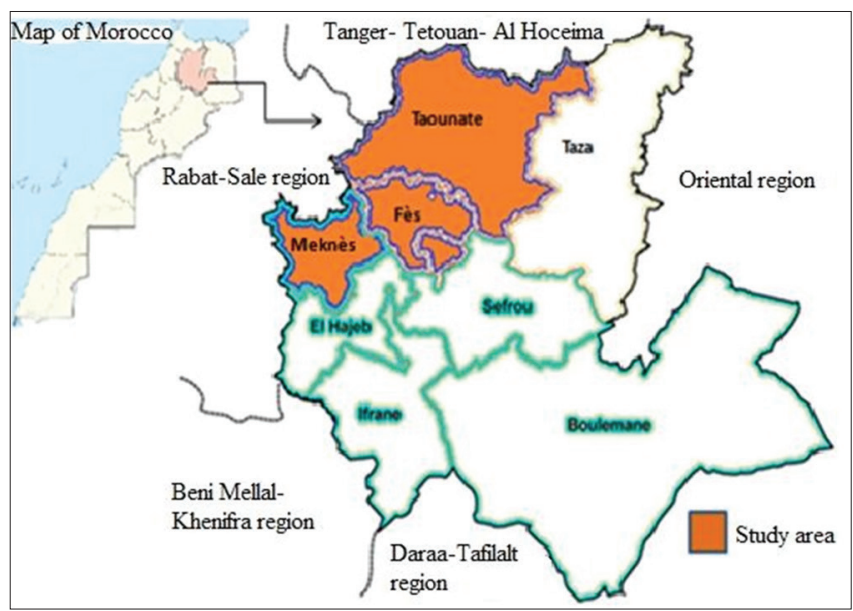

Fig. 1: Map of the studied areas

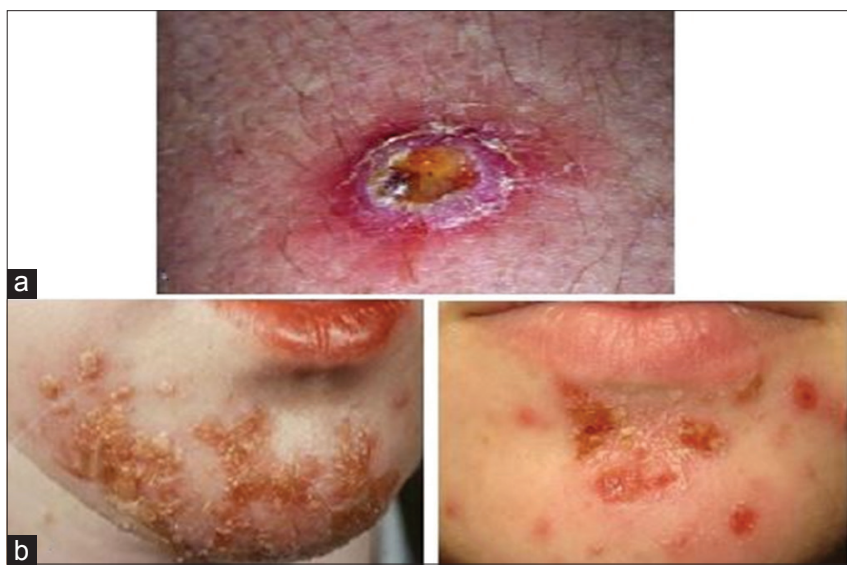

Fig. 2: Example of dermatitis photos showed to the herbalists in the studied region. (a) Furunculosis. (b) Impetigo were collected from the field; voucher specimens of each plant were identified by a specialist (from the Scientific Institute in RabatMorocco) and then deposited at a herbarium in Laboratory of Microbial Biotechnology in Faculty of Sciences and Techniques in Sidi Mohamed Ben Abdellah University of Fez-Morocco. The frequency index (FI) was calculated for each plant to evaluate the importance of each plant using the following formula:

\section{$\mathrm{FI}=\mathrm{n} / \mathrm{N}^{*} 100$}

n: Total number of herbalists who listed a particular plant species. $\mathrm{N}$ : Total number of interviewed herbalists.

\section{Plants selection and preparation}

Certainly, the local population usually uses the decoction mode to prepare remedies. However, our findings in a previous study show that aqueous extracts have not shown any antibacterial activity due to the influence of solvents nature and polarity. For this reason, ethanol extracts of the seventeen most common plants cited by the healers ( $\mathrm{FI} \geq 8.88 \%$ ) have been prepared in accordance to the methods described by Elaloui et al. and Yeo et al. with slight modifications $[17,18]$. The used part of each plant as mentioned by herbalists was grounded to powder, and then $10 \mathrm{~g}$ of the powder of each plant was macerated in $100 \mathrm{ml}$ of ethanol under agitation (500 rpm), at room temperature for $6 \mathrm{~h}$. The resulting mixture was filtered through Whatman filter $n^{\circ} 1$ then evaporated under vacuum. Dried extracts were stored in a refrigerator at $4^{\circ} \mathrm{C}$ until further use.

\section{ANTISTAPHYLOCOCCAL TESTING}

\section{Target microorganisms}

The prepared ethanolic extracts have been the objective for the antistaphylococcal activity using agar well diffusion method and the minimum inhibitory concentrations (MIC) determination against strains often involved in cutaneous infections including $S$. aureus ATCC 29213, S. aureus clinical isolate, and Staphylococcus epidermidis ATCC 12228. The antibiogram profile of strains' bacteria was identified at the Laboratory of Bacteriology in Fez-Morocco, and it has shown that both S. aureus strains are methicillin-resistant (Table 1).

Agar well diffusion method

Revivification of bacteria has been performed by subculturing the agar plate surface Luria-Bertani (LB) pre-poured in Petri dishes and incubated at $37^{\circ} \mathrm{C}$ for 18 to $24 \mathrm{~h}$. The microbial inoculums were obtained from fresh colonies through the direct colony suspension method. Hence, 1-2 colonies were suspended in sterile saline $(\mathrm{NaCl} 0.9 \%)$ and adjusted to 0.5 McFarland scale $\left(10^{8}\right.$ colony-forming unit $\left./ \mathrm{ml}\right)$. Agar well diffusion method as described in Balouiri et al. [19] was used to evaluate the antimicrobial activity. The agar surface was inoculated

Table 1: Antibiogram profile of the targets bacterial strains

\begin{tabular}{|c|c|c|c|c|}
\hline Antibiotic family & Antibiotic & Dose per disk ( $\mu \mathrm{g})$ & S. epidermidis & S. aureus ATCC 29213 S. aureus clinical isolate \\
\hline \multirow[t]{5}{*}{ Penicillins } & Penicillin & 10 units & Susceptible & Resistant \\
\hline & Ampicillin & 10 & Susceptible & Resistant \\
\hline & Amoxicillin & 20 & Susceptible & Resistant \\
\hline & Oxacillin & 1 & Susceptible & Resistant \\
\hline & Methicillin & 5 & Susceptible & Resistant \\
\hline Penicillin combinations & Amoxicillin/Clavulanate & $20 / 10$ & Susceptible & Resistant \\
\hline Cephalosporins & Ceftriaxone & 30 & Susceptible & Resistant \\
\hline \multirow[t]{2}{*}{ Glycopeptides } & Vancomycin & 30 & Susceptible & Susceptible \\
\hline & Teicoplanin & 30 & Susceptible & Susceptible \\
\hline \multirow{2}{*}{ Macrolides } & Erythromycin & 15 & Susceptible & Resistant \\
\hline & Spiramycin & 15 & Susceptible & Resistant \\
\hline Tetracyclines & Tetracycline & 30 & Resistant & Susceptible \\
\hline Polypeptides & Colistin & 10 & Resistant & Resistant \\
\hline \multirow[t]{2}{*}{ Others } & Fusidic acid & 10 & Susceptible & Resistant \\
\hline & Pristinamycin & 10 & Susceptible & Susceptible \\
\hline
\end{tabular}

S. aureus: Staphylococcus aureus, S. epidermidis: Staphylococcus epidermidis 
Table 2: The inventorying ethno dermatological medicinal plants

\begin{tabular}{|c|c|c|c|c|c|c|}
\hline Botanical name & Family name & Local name & Part used & $\begin{array}{l}\text { Administration } \\
\text { route }\end{array}$ & $\begin{array}{l}\text { Preparation } \\
\text { mode }\end{array}$ & FI (\%) \\
\hline $\begin{array}{l}\text { Allium ampeloprasum } \\
\text { (=Allium porrum) }\end{array}$ & Alliaceae & Krrat & Leave flower & Cutaneous & Decoction & $2.22(\mathrm{FS})$ \\
\hline Aloe vera & Aloeaceae & Alovera & Leaves & Cutaneous & $\begin{array}{l}\text { Cataplasme } \\
\text { decoction } \\
\text { infusion }\end{array}$ & $5.88(\mathrm{TN})$ \\
\hline Daucus carota & Apiaceae & Khizzo/Jaada & Whole plant fruit & Cutaneous & $\begin{array}{l}\text { Decoction } \\
\text { cataplasme }\end{array}$ & $2.22(\mathrm{FS})$ \\
\hline Petroselinum crispum & Apiaceae & Maadnous & Leaves & Oral & $\begin{array}{l}\text { Infusion } \\
\text { decoction }\end{array}$ & $2.22(\mathrm{FS})$ \\
\hline Ammi majus & Apiaceae & Trillan/Tlillan & Leaves & Cutaneous & Decoction & $\begin{array}{l}8.88(\mathrm{FS}) 11.76 \\
(\mathrm{TN})\end{array}$ \\
\hline Ammi visnaga & Apiaceae & $\begin{array}{l}\text { El khella el bariya/ } \\
\text { Bechnikha; Kessiba }\end{array}$ & Leave Root & Cutaneous & $\begin{array}{l}\text { Cataplasme } \\
\text { decoction }\end{array}$ & $2.22(\mathrm{FS})$ \\
\hline Ferula assa - foetida & Apiaceae & Elwachk & Leaves flowers & Cutaneous & $\begin{array}{l}\text { Cataplasme } \\
\text { decoction }\end{array}$ & $2.22(\mathrm{FS})$ \\
\hline Nerium oleander & Apocynaceae & Defla & $\begin{array}{l}\text { Leaves whole plant } \\
\text { arial part }\end{array}$ & Cutaneous & Cataplasme & $8.88(\mathrm{FS})$ \\
\hline Artemisia herba alba & Asteraceae & Chih & Leaves & Cutaneous & Cataplasme & $\begin{array}{l}4.44(\mathrm{FS}) 17.64 \\
(\mathrm{MK}) 5.88(\mathrm{TN})\end{array}$ \\
\hline $\begin{array}{l}\text { Dittrichia viscosa } \\
=(\text { Inula viscosa })\end{array}$ & Asteraceae & $\begin{array}{l}\text { Magraman } \\
\text { bayraman }\end{array}$ & Leaves whole plant & Cutaneous & Cataplasme & $\begin{array}{l}20(\mathrm{FS}) 17.64 \\
(\mathrm{MK}) 17.64(\mathrm{TN})\end{array}$ \\
\hline Chamaemelum nobile & Asteraceae & Babounj & Leaves & Oral & Infusion & $\begin{array}{l}2.32(\mathrm{FS}) 6.25 \\
(\mathrm{MK})\end{array}$ \\
\hline $\begin{array}{l}\text { Carlina gummifera } \\
\text { (=Atractylis } \\
\text { gummifera }=\end{array}$ & Asteraceae & Addad & Roots & Cutaneous & Cataplasme & $2.22(\mathrm{FS})$ \\
\hline Berberis hispanica & Berberidaceae & Azirki arghis & Roots & Cutaneous & Cataplasme & $\begin{array}{l}8.88(\mathrm{FS}) 11.76 \\
(\mathrm{MK}) 5.88(\mathrm{TN})\end{array}$ \\
\hline Lepidium sativum & Brassicaceae & Heb errechad & Seeds & Oral & Decoction & $5.88(\mathrm{TN})$ \\
\hline Eruca sativa & Brassicaceae & El Gergir/ Jerjir & Flowers seeds & Oral & Decoction & 8.88 (FS) \\
\hline Juniperus oxycedrus & Cupressaceae & Taqqa, tiqqi & Seeds & Cutaneous & $\begin{array}{l}\text { Decoction } \\
\text { cataplasme }\end{array}$ & $\begin{array}{l}11.11(\mathrm{FS}) 17.64 \\
(\mathrm{TN})\end{array}$ \\
\hline Ricinus communis & Euphorbiaceae & El kharwaae & Leaves & Cutaneous & $\begin{array}{l}\text { Cataplasme } \\
\text { decoction }\end{array}$ & $5.88(\mathrm{TN})$ \\
\hline Glycyrrhiza glabra & Fabaceae & Erk sous & Roots & Cutaneous & Decoction & $2.22(\mathrm{FS})$ \\
\hline Cicer arietinum & Fabaceae & Hemess & Fruit & Cutaneous & Cataplasme & $2.22(\mathrm{FS})$ \\
\hline Pelargonium graveolens & Geraniaceae & Laatercha & Leaves flowers & Cutaneous & Decoction & $2.22(\mathrm{FS})$ \\
\hline Illicium verum & Illiciaceae & Badiyan & Whole plant seed & Oral cutaneous & $\begin{array}{l}\text { infusion } \\
\text { cataplasme }\end{array}$ & $2.22(\mathrm{FS})$ \\
\hline Crocus sativus & Iridaceae & Zaafrane & Stigma & Cutaneous & Decoction & $2.22(\mathrm{FS})$ \\
\hline $\begin{array}{l}\text { Juncus rigidus(= Juncus } \\
\text { arabicus) }\end{array}$ & Juncaceae & $\begin{array}{l}\text { Oud essemar/smar; } \\
\text { your }\end{array}$ & Roots & Cutaneous & Cataplasme & $5.88(\mathrm{TN})$ \\
\hline Thymus algeriensis & Lamiaceae & Zaater, marrad & Whole plant leaves & Oral & Infusion & $\begin{array}{l}6.66(\mathrm{FS}) 5.88 \\
(\mathrm{MK}) 5.88(\mathrm{TN})\end{array}$ \\
\hline Lavandula dentata & Lamiaceae & Khiyata & $\begin{array}{l}\text { Leaves flowers } \\
\text { whole plant }\end{array}$ & Oral & Infusion & $\begin{array}{l}4.44(\mathrm{FS}) 5.88 \\
(\mathrm{MK}) 5.88(\mathrm{TN})\end{array}$ \\
\hline Mentha piperita & Lamiaceae & $\begin{array}{l}\text { Naânaâ Elfolfoli, } \\
\text { Naânaâ El Âbdi }\end{array}$ & Leaves & Oral cutaneous & Infusion & $2.22(\mathrm{FS})$ \\
\hline Thymus atlanticus & Lamiaceae & Zîitra & Leaves & Oral cutaneous & $\begin{array}{l}\text { Decoction } \\
\text { cataplasme }\end{array}$ & $2.22(\mathrm{FS})$ \\
\hline Origanum majorana & Lamiaceae & $\begin{array}{l}\text { Merdedouch/ } \\
\text { Berkdouch }\end{array}$ & Leaves whole plant & Cutaneous & Decoction & $\begin{array}{l}11.11 \text { (FS) } 17.64 \\
(\mathrm{TN})\end{array}$ \\
\hline Lavandula angustifolia & Lamiaceae & Khzama & $\begin{array}{l}\text { Leaves flower } \\
\text { whole plant }\end{array}$ & Oral & Infusion & $5.88(\mathrm{MK})$ \\
\hline Marrubium vulgare & Lamiaceae & Meriwta, marriwa & $\begin{array}{l}\text { Leaves flowers } \\
\text { whole plant }\end{array}$ & Cutaneous & Decoction & $5.88(\mathrm{MK})$ \\
\hline Rosmarinus officinalis & Lamiaceae & Azir & Leaves & Oral cutaneous & Infusion & $2.22(\mathrm{FS})$ \\
\hline Ocimum canum & Lamiaceae & Errayhan el kafouri & Leaves & Oral & Decoction & $2.22(\mathrm{FS})$ \\
\hline Salvia officinalis & Lamiaceae & Salmiya & Leaves & Cutaneous & Cataplasme & 2.22 (FS) \\
\hline Punica granatum & Lythraceae & Romman & Peel & Cutaneous & Decoction & $\begin{array}{l}11.11 \text { (FS) } 23.52 \\
(\mathrm{MK})\end{array}$ \\
\hline Lawsonia inermis & Lythraceae & El Henna & Leaves & Cutaneous & Cataplasme & 2.22 (FS) \\
\hline
\end{tabular}


Table 2: (Continued)

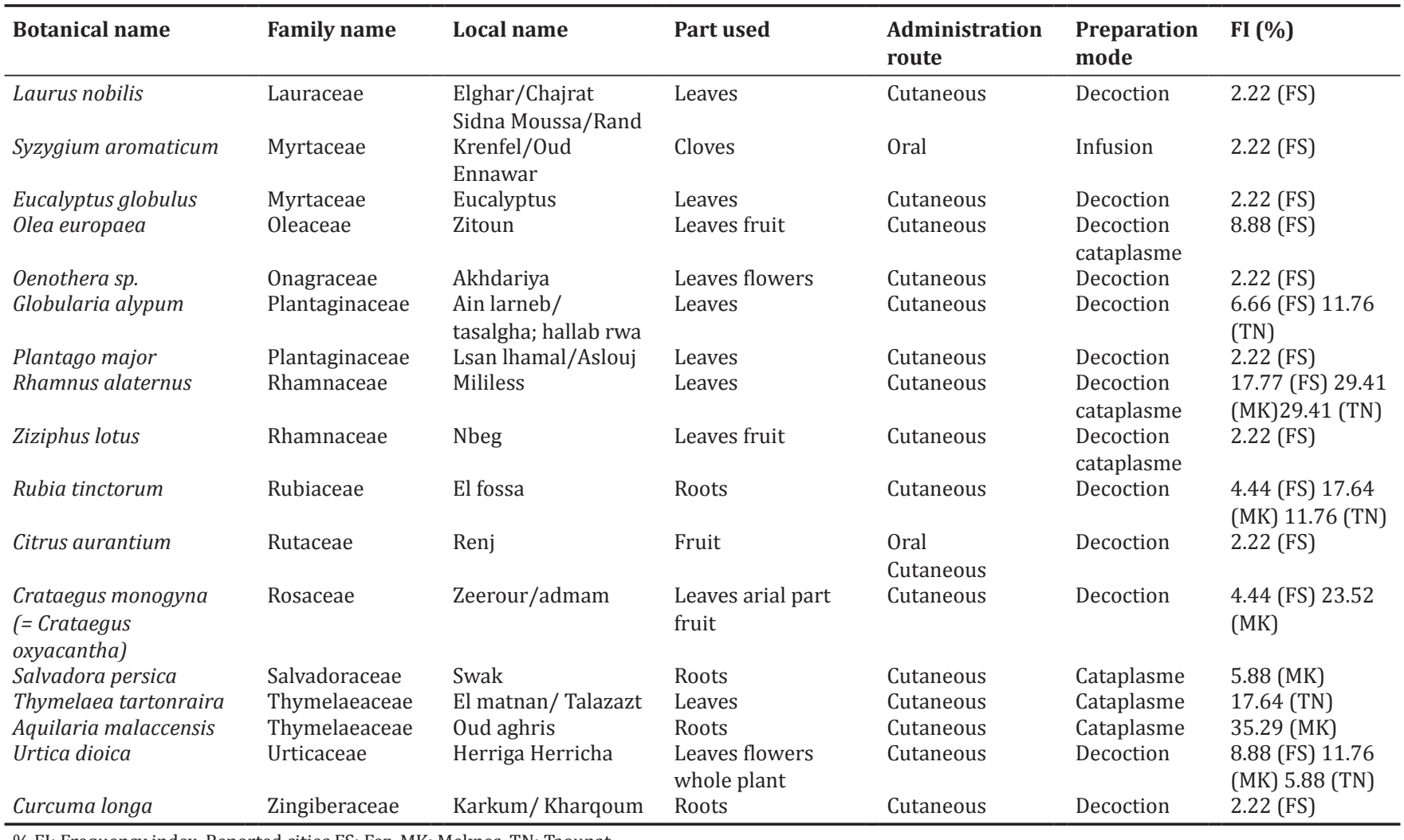

\% FI: Frequency index, Reported cities FS: Fez, MK: Meknes, TN: Taounat

spreading bacterial inoculums. After 30 min of the drying process in ambient temperature and inoculums' diffusion, a hole with a diameter of $6 \mathrm{~mm}$ was punched aseptically using a tip, then $80 \mu \mathrm{l}$ of each extract solution $(50 \mathrm{mg} / \mathrm{ml})$ were introduced into the wells. Finally, agar plates were incubated for $24 \mathrm{~h}$ at $37^{\circ} \mathrm{C}$. Distilled water was used as negative control, while ampicillin $(100 \mu \mathrm{g} / \mathrm{ml})$ was used as positive control. After measuring the diameter of inhibition's zones around the well, means were calculated, and then the active extracts were subjected to the determination of the MIC

\section{Determination of the MIC}

The MIC was determined following the agar dilution method described by Balouiri et al. with slight modifications [19]. It involves the incorporation of varying concentrations of extract as an antimicrobial agent into the agar medium before its solidification. Different concentrations of each extract ranging from 50 to $160 \mathrm{mg} / \mathrm{ml}$ per factor of (2) were prepared in dimethyl sulfoxide (20\%), and $1 \mathrm{ml}$ of each dilution was incorporated in $9 \mathrm{ml}$ of medium culture (sterile and soft LB). The mixture was grounded carefully and distributed into Petri dishes. After medium's solidification, and from a suspension adjusted to $10^{5} \mathrm{UFC} / \mathrm{ml}$, volumes of $5 \mu \mathrm{l}$ were deposited on agar surface as spots. Finally, the dishes were incubated for $24 \mathrm{~h}$ at $37^{\circ} \mathrm{C}$. A growth control was prepared without plant extracts.

\section{QUANTITATIVE PHYTOCHEMICAL ANALYSIS}

\section{Total phenolic quantification}

The quantification of total phenolic has been evaluated using the Folin-Ciocalteu reagent by introducing $1.5 \mathrm{ml}$ of Folin-Ciocalteu reagent $(10 \%)$ in $200 \mu \mathrm{l}$ of extract $(1 \mathrm{mg} / \mathrm{ml}$ Ethanol), the mixture was agitated carefully and allowed to react for $5 \mathrm{~min}$ in dark, then followed by adding $1.5 \mathrm{ml}$ of sodium carbonate (5\%). After $2 \mathrm{~h}$ of incubation in room temperature and in the dark again, values have been read using spectrophotometer visible-ultraviolet (UV) at $750 \mathrm{~nm}$. Under the same conditions, a calibration range was made using gallic acid with different concentrations ranging between $300 \mu \mathrm{g} / \mathrm{ml}$ and $25 \mu \mathrm{g} / \mathrm{ml}$. The total phenolic content was expressed as $\mu$ g gallic acid equivalents per mg dry weight of the extract ( $\mu \mathrm{g}$ GA eq mg E)

\section{Total flavonoids quantification}

The flavonoid content has been determined as described in Bahorun et al. [20]. Technically, $0.5 \mathrm{ml}$ of each extract was mixed with $0.1 \mathrm{ml}$ of aluminum chloride (10\%), $0.1 \mathrm{ml}$ of potassium acetate $(1 \mathrm{~m})$, and $4.3 \mathrm{ml}$ of distilled water; after a vigorous agitation, the mixture was incubated for $30 \mathrm{~min}$ in ambient temperature. DO's values have been read using spectrophotometer visible-UV at $415 \mathrm{~nm}$. Flavonoid content was expressed as $\mu \mathrm{g}$ Quercetin equivalents per mg dry weight of the extract ( $\mu \mathrm{g}$ Quer eq mg E) using a calibration range from 25 to $300 \mu \mathrm{g} / \mathrm{ml}$.

\section{Data analysis}

The data collected from the ethnobotanical surveys have been analyzed using Excel software. The other results have been presented as means values \pm standard deviation, and statistical analyses were performed using analysis of variance by IBM SPSS Statistics 21. Differences at $\mathrm{p}<0.05$ were considered statistically significant.

\section{RESULTS}

\section{Ethnobotanical survey}

In the present survey, 91 traditional herbalists and healers ( $\mathrm{n}=91)$ from provinces of Fez (FS), Meknes (MK) and Taounate (TN) were interviewed. 55 plant species distributed in 30 families were mentioned (Table 2). The most representative family was the Lamiaceae (18.18\%) with 10 species, followed by the Apiaceae $(10.91 \%)$ with 6 species and the Asteraceae (7.27\%) with 4 species. Other families have been presented by one or two species.

On the one hand, leaves were the most frequently cited used part to prepare remedies with $45 \%$, followed by roots or whole plant with $12.5 \%$ each, then flowers $(11.25 \%)$. The remedies were prepared 
using decoctions in water as solvent (48.53\%), followed by cataplasm with $35.29 \%$. Most of the anti-cutaneous infections preparations were administered externally (75\%) against $25 \%$ orally.

On the other hand, the calculated FI has indicated that the most frequently cited (FI>8.88\%) anti-dermatitis plant species in the three studied areas were Rhamnus alaternus (FI (FS) $=17.77 \%$; FI $(\mathrm{MK})=29.41 \%$; FI $(\mathrm{TN})=29.41 \%)$, Punica granatum $(\mathrm{FI}(\mathrm{FS})=11.11 \%$; and FI $(\mathrm{MK})=23.52 \%) ;$ Dittrichia (Inula) viscosa $\quad(\mathrm{FI}(\mathrm{FS})=20 \%$; FI(MK/TN) $=17.64 \%)$, Alkkanna tinctoria $(\mathrm{FI}(\mathrm{MK})=23.52 \%)$, Aquilaria malaccensis (FI $(\mathrm{MK})=35.29 \%) ;$ Urtica dioica (FI $(\mathrm{FS})=8.88 \%$; FI $(\mathrm{MK})=11,76 \%)$, Crataegus monogyna $(\mathrm{FI}(\mathrm{MK})=23.52 \%)$, Origanum majorana $(\mathrm{FI}(\mathrm{FS})=11.11 \%$; FI $(\mathrm{TN})=17.64 \%)$, Juniperus oxycedrus (FI (FS) $=11.11 \%$; FI $(\mathrm{TN})=17.64 \%)$, Artemisia herba alba (FI $(\mathrm{MK})=17.64 \%)$, Berberis hispanica $($ FI $(\mathrm{FS})=8.88 \%$; FI $(\mathrm{MK})=11.76 \%)$, Rubia tinctorum (FI (MK)=17.64\%; FI $(\mathrm{TN})=11.76 \%)$, Thymelaea tartonraira $(\mathrm{FI}(\mathrm{TN})=17.64 \%)$, Globularia alypum $(\mathrm{FI}(\mathrm{TN})=11.76 \%)$, and Ammi majus (FI (FS)=8.88\%; FI (TN)=11.76\%), then Nerium oleander, Eruca sativa, Olea europea with FI (FS) $=8.88 \%$. Aquilaria malaccensis has presented an important score of citation; however, it is not from Morocco and especially Fez-Meknes region, the species is reported from Asia so for that we didn't test it.

\section{Antistaphylococcal activity}

The crude ethanolic extracts of the 17 most cited plants were tested against $S$. epidermidis, and two MRSA clinical isolate and $S$. aureus reference. The data pertaining to the in vitro assay are presented in Tables 3 and 4 . The obtained data have revealed that among the 17 tested plants, nine were active against the target strains, and eight plant extracts have not shown antistaphylococcal activity. The quantitative determination of MIC values has shown that the antibacterial activity varied on the plant species and the target microorganism.

Both extracts from P. granatum peel and R. alaternus leaves have registered the highest effect against the three Staphylococcus strains with a MIC ranging between 0.25 and $2.00 \mathrm{mg} / \mathrm{ml}$.

In the other side, I. viscosa leaves extract has exhibited the same effect with with MIC of $4.00 \mathrm{mg} / \mathrm{ml}$ against the three strains which were the same for 0 . majorana expect for $S$. epidermidis that its MIC was superior to $16.00 \mathrm{mg} / \mathrm{ml}$. O. europea has also inhibited the growth of $S$. aureus clinical isolate at $4.00 \mathrm{mg} / \mathrm{ml}$, but it was effective against $S$. aureus reference at MIC of $08.00 \mathrm{mg} / \mathrm{ml}$ and more than $16.00 \mathrm{mg} / \mathrm{ml}$ for $S$. epidermidis. In addition, the MIC values of the other active plant extracts were ranging from $08.00 \mathrm{mg} / \mathrm{ml}$ to upper than $16.00 \mathrm{mg} / \mathrm{ml}$ against the tested strains.

\section{Quantitative phytochemical assays}

The total phenolic and total flavonoids contents of the 17 extracts were presented in Table 5. As can be noted from this table, 0 . majorana and 0 . europaea have presented the highest content of total phenols $(307.87 \pm 0.12 \mu \mathrm{g}$ eq $\mathrm{GA} / \mathrm{mg} \mathrm{E}$ and $297.51 \pm 6.45 \mu \mathrm{g}$ eq $\mathrm{GA} / \mathrm{mg} \mathrm{E}$, respectively), followed by $P$. granatum extract which has noticed $153.41 \pm 4.36 \mu \mathrm{g} \mathrm{eq} \mathrm{GA} / \mathrm{mg}$ E, then $R$. alaternus with $119.38 \pm 3.71 \mu \mathrm{g}$ eq $\mathrm{GA} / \mathrm{mg}$ E. I. viscosa and C. oxyacantha extracts were in the same rang with $88.63 \pm 3.12 \mu \mathrm{g}$ eq $\mathrm{GA} / \mathrm{mg} \mathrm{E}$ and $113.60 \pm 1.88 \mu \mathrm{g}$ eq $\mathrm{GA} / \mathrm{mg} \mathrm{E}$, respectively. The total phenols amount of the other plant extracts were ranging from $57.98 \pm 2.66 \mu \mathrm{g}$ eq $\mathrm{GA} / \mathrm{mg}$ E to $5.95 \pm 0.99 \mu \mathrm{g}$ eq $\mathrm{AG} / \mathrm{mg}$ d'E. Nerium oleander, Eruca sativa, and Alkanna tinctoria extracts have indicated the lowest concentration of total phenols in comparison with the other extracts $(\mathrm{p}<0.05)$.

Regarding to flavonoids, the first range belonged to $R$. alaternus with a content of $321.03 \pm 0.63 \mu \mathrm{g}$ eq Que/mg E, followed by $P$. granatum extract $(125.07 \pm 3.90 \mu \mathrm{g}$ eq Que/mg d'E) and E. sativa $(152.53 \pm 4.85 \mu \mathrm{g}$ eq Que/mg E), then 0 . europaea with $83.54 \pm 1.92 \mu \mathrm{g}$ eq Que/mg E, followed by Ammi majus, Thymelaea tartonraira, Origanum majorana, Artemisia herba alba, Juniperus oxycedrus, Crataegus oxyacantha, and Inula viscosa, the flavonoid contents of these plants were
Table 3: Antibacterial screening of the plant extracts using the agar well-diffusion method

\begin{tabular}{|c|c|c|c|}
\hline \multirow[t]{2}{*}{ Plant extracts } & \multicolumn{3}{|c|}{ Target microorganisms } \\
\hline & S. epidermidis & $\begin{array}{l}\text { S. aureus } \\
\text { clinical isolate }\end{array}$ & $\begin{array}{l}\text { S. aureus } \\
\text { ATCC } 29213\end{array}$ \\
\hline Punica granatum & $22.3 \pm 1.24$ & $25.00 \pm 1.00$ & $24.66 \pm 0.47$ \\
\hline $\begin{array}{l}\text { Rhamnus } \\
\text { alaternus }\end{array}$ & $16.00 \pm 1.00$ & $25.50 \pm 1.5$ & $25.00 \pm 1.00$ \\
\hline Inula viscosa & $11.66 \pm 1.24$ & $13.66 \pm 1.88$ & $13.00 \pm 0.81$ \\
\hline $\begin{array}{l}\text { Crataegus } \\
\text { oxyacantha }\end{array}$ & $14.00 \pm 0.81$ & $12.33 \pm 1.88$ & $11.66 \pm 1.24$ \\
\hline Rubia tinctorium & $13.33 \pm 1.24$ & $10.33 \pm 0.47$ & $12.50 \pm 0.50$ \\
\hline $\begin{array}{l}\text { Artemisia herba } \\
\text { alba }\end{array}$ & $7.00 \pm 0.00$ & $14.50 \pm 2.12$ & $13.00 \pm 0.70$ \\
\hline $\begin{array}{l}\text { Berberis } \\
\text { hispanica }\end{array}$ & $24.00 \pm 0.00$ & $26.00 \pm 1.00$ & $24.00 \pm 1.00$ \\
\hline Olea europaea & $25.33 \pm 0.94$ & $14.50 \pm 0.5$ & $14.00 \pm 0.81$ \\
\hline $\begin{array}{l}\text { Origanum } \\
\text { majorana }\end{array}$ & $08.00 \pm 0.00$ & $10.00 \pm 0.81$ & $11.00 \pm 0.81$ \\
\hline Nerium oleander & - & - & - \\
\hline Alkanna tinctoria & - & - & - \\
\hline $\begin{array}{l}\text { Juniperus } \\
\text { oxycedrus }\end{array}$ & - & - & - \\
\hline Eruca sativa & - & - & - \\
\hline Urtica dioica & - & - & - \\
\hline $\begin{array}{l}\text { Thymelaea } \\
\text { tartonraira }\end{array}$ & - & - & - \\
\hline $\begin{array}{l}\text { Globularia } \\
\text { alypum }\end{array}$ & - & - & - \\
\hline Ammi majus & - & - & - \\
\hline Ampicillin & 17.0 & - & 07.0 \\
\hline
\end{tabular}

Non active: Data represents mean \pm standard error of mean.

S. aureus: Staphylococcus aureus, S. epidermidis: Staphylococcus epidermidis

Table 4: MICs $(\mathrm{mg} / \mathrm{ml})$ of the most active studied extracts

\begin{tabular}{llll}
\hline $\begin{array}{l}\text { Ethanolic } \\
\text { extracts }\end{array}$ & \multicolumn{1}{l}{ CMI (mg/ml) } & & \\
\cline { 2 - 4 } & $\begin{array}{l}\text { S. aureus } \\
\text { clinical isolate }\end{array}$ & $\begin{array}{l}\text { S. aureus } \\
\text { ATCC 29213 }\end{array}$ & S. epidermidis \\
\hline $\begin{array}{l}\text { Artemisia } \\
\text { herba alba }\end{array}$ & 8.00 & 8.00 & 8.00 \\
$\begin{array}{l}\text { Berberis } \\
\text { hispanica }\end{array}$ & 16.00 & 16.00 & $>16.00$ \\
$\begin{array}{l}\text { Crataegus } \\
\text { oxyacantha }\end{array}$ & 16.00 & 16.00 & 8.00 \\
$\begin{array}{l}\text { Inula viscosa } \\
\begin{array}{l}\text { Olea europaea } \\
\text { Origanum }\end{array}\end{array}$ & 4.00 & 4.00 & 4.00 \\
$\begin{array}{l}\text { majorana } \\
\begin{array}{l}\text { Punica granatum } \\
\text { Rhamnus }\end{array}\end{array}$ & 1.00 & 8.00 & $>16.00$ \\
$\begin{array}{l}\text { alaternus } \\
\text { Rubia tinctorum }\end{array}$ & 16.00 & 4.00 & $>16.00$ \\
\hline
\end{tabular}

S. aureus: Staphylococcus aureus, S. epidermidis: Staphylococcus epidermidis, MICs: Minimum inhibitory concentrations

between $73.64 \pm 1.47$ and $49.90 \pm 2.80 \mu \mathrm{g}$ eq Que/mg E. Berberis hispanica and Alkanna tinctoria extracts have shown the lowest total flavonoids content (14.75 \pm 3.18 and $12.17 \pm 2.36 \mu \mathrm{g} \mathrm{eq} / \mathrm{mg}$ E, respectively).

\section{DISCUSSION}

The current survey realized in three areas in the central north of Morocco aimed the identification of plants used in the treatment of skin infections, the in vitro evaluation of the most recommended plants against Staphylococcus strains often involved in dermatitis and the analysis of phytochemical compounds that could be responsible for skin care. 
Table 5: Total phenolic and flavonoids contents of the ethanolic extracts

\begin{tabular}{|c|c|c|}
\hline Plants & $\begin{array}{l}\text { Total phenolic } \\
\text { contents } \\
\text { ( } \mu \text { g equivalent of } \\
\text { gallic acid/mg of } \\
\text { extract) }\end{array}$ & $\begin{array}{l}\text { Total flavonoid } \\
\text { contents } \\
\text { ( } \mu \text { g equivalent of } \\
\text { quercetin/mg of } \\
\text { extract) }\end{array}$ \\
\hline Punica granatum & $153.41 \pm 4.36^{\mathrm{b}}$ & $125.07 \pm 3.90^{\mathrm{b}, \mathrm{c}}$ \\
\hline Rhamnus alaternus & $119.38 \pm 3.71^{b, c}$ & $321.03 \pm 0.63^{\mathrm{a}}$ \\
\hline Inula viscosa & $88.63 \pm 3.12^{\mathrm{c,d}}$ & $57.74 \pm 6.58^{c, d}$ \\
\hline Crataegus oxyacantha & $113.60 \pm 1.88^{\mathrm{c,d}}$ & $57.01 \pm 5.38^{\mathrm{c}, \mathrm{d}}$ \\
\hline Rubia tinctorum & $51.37 \pm 3.64^{\mathrm{f}, \mathrm{g}}$ & $22.95 \pm 2.82^{\mathrm{d}}$ \\
\hline Artemisia herba alba & $52.68 \pm 3.61^{\mathrm{e}, \mathrm{f}}$ & $52.26 \pm 0.77^{\mathrm{c}, \mathrm{d}}$ \\
\hline Origanum majorana & $307.87 \pm 0.12^{\mathrm{a}}$ & $73.64 \pm 1.47^{\mathrm{c}, \mathrm{d}}$ \\
\hline Berberis hispanica & $50.77 \pm 8.34^{\mathrm{f}, \mathrm{g}}$ & $14.75 \pm 3.18^{\mathrm{d}}$ \\
\hline Globularia alypum & $52.45 \pm 2.71^{\mathrm{e}, \mathrm{f}}$ & $43.99 \pm 1.79^{d}$ \\
\hline Olea europaea & $297.51 \pm 6.45^{\mathrm{a}}$ & $83.54 \pm 1.92^{\mathrm{b}, \mathrm{c}, \mathrm{d}}$ \\
\hline Nerium oleander & $5.95 \pm 0.99^{i}$ & $19.76 \pm 0.51^{\mathrm{d}}$ \\
\hline Alkanna tinctoria & $8.50 \pm 3.40^{\mathrm{i}}$ & $12.17 \pm 2.36^{\mathrm{d}}$ \\
\hline Juniperus oxycedrus & $16.63 \pm 10.63^{\mathrm{h}, \mathrm{i}}$ & $67.00 \pm 5.25^{\mathrm{c,d}}$ \\
\hline Eruca sativa & $9.25 \pm 0.88^{i}$ & $152.53 \pm 4.85^{b}$ \\
\hline Urtica dioica & $13.29 \pm 0.56^{\mathrm{i}}$ & $33.00 \pm 0.94^{\mathrm{d}}$ \\
\hline Thymelaea tartonraira & $57.98 \pm 2.66^{\mathrm{e}, \mathrm{f}}$ & $62.67 \pm 1.97^{\mathrm{c}, \mathrm{d}}$ \\
\hline Ammi majus & $28.20 \pm 5.88^{\mathrm{ghh}}$ & $60.59 \pm 5.53^{\mathrm{c}, \mathrm{d}}$ \\
\hline
\end{tabular}

Means that not share the same letter are statistically different at $\mathrm{p}<0.05$. Data represent mean \pm standard error of mean

In the present study, 55 medicinal plants belonging to 30 families have been prescribed by herbalists and traditional healers in Fez, Meknes, and Taounate to cure skin disorders that can be caused by the Staphylococcus genus. The Lamiaceae family was the most abundant $(18.18 \%)$. This family has been demonstrated to have antibacterial and antifungal activities against skin infections [21]. Furthermore, several pharmacological properties have been attributed to this family due to its richness in active bio-molecules. Admittedly there has been a qualitative and quantitative difference in chemical composition of species belonging to the Lamiaceae family or else the same genus [22], but this family stills generally rich in polyphenols, saponins, irroides, alkaloids, anthocyanins, and aldehydes [23]. Those compounds possess broad-spectrum antimicrobials [24].

The obtained results have also revealed that (i) the leaves were the most used part (45\%) which accords other studies [24]. This extensive use could be explained by the abundance of phytochemical compounds in leaves which are the synthesis site of vegetal secondary metabolites [25]; (ii) decoction mode was the most recommended (48.53\%). Many investigations concerning the plants' uses in traditional medicine have highlighted the preponderance of decoction method to prepare remedies [26,27] which appears to have a number of advantages like the extraction of the maximum of herbal substances that are soluble in boiling water which makes them easily absorbed and perceived by human body [28]; (iii) external administration route was in the first ring (75.00\%) including flushing and cataplasm depending on the patient preference. This is may be explained by the fact that both of methods could be fast and efficient. The internal use of medicinal plants consisted, for example, tract digestive disease, stomachache, or rheumatism pain. However, skin infections need the use of external remedies which is in agreement with literature $[29,30]$

Nine of the most recommended plant species reported in the current survey were found to be efficient against the three studied Staphylococcus strains. These plants included P. granatum, $R$. alaternus, I. viscosa, O. europea, O. majorana, C. oxyacantha, $R$. tinctorium, $A$. herba alba, and $B$. hispanica. In some cases, these findings support the traditional uses of the inventorying plant species through the ethnobotanical study.
Many previous investigations have confirmed the significant antibacterial activity of these plants against various bacterial species including $S$. aureus. Indeed, the anti-staphylococcus activity of $B$. hispanica extract is in agreement with a previous study that has reported the effect of ethanolic extract of $B$. hispanica roots against $S$. aureus [31]. Stelmakiene et al. [32] reported that the aqueous extract of $C$. oxyacantha leaves has revealed antistaphylococcal activity against $S$. aureus and $S$. epidermidis.

A number of studies have also been reported to confirm that P. granatum is effective in skin curing and protection. The extract of $P$ granatum has been mentioned as one of the ingredients in skin care formulations of an interesting invention [33]. This plant species has been also acclaimed to have a protective effect award UltravioletIrradiated Human Skin Fibroblasts that could cause serious skin disorders $[34,35]$. The antistaphylococcal activity of $P$. granatum has been also demonstrated; a previous study has shown that the ethanolic extract prepared from $P$. granatum pericarp was effective against $S$. aureus and S. epidermidis [36].

The antibacterial activity of $R$. alaternus has been also evaluated against pathogenic bacteria; the leaves' extract was efficient against $S$. aureus [37]. Other in vitro investigations have also confirmed the antibacterial activity (especially against staphylococcus genus) of the extract prepared from the leaves of I. viscosa [38], O. europea [39], $O$. majorana [40], and the roots of $R$. tinctorium [41]. Among A. herba $a l b a$, it has proven its medicinal use for centuries as an antimicrobial agent [42].

However, our findings have noticed that eight of the most recommended plants have not shown any anti-staphylococcal potent, these extracts may have other biological activities against other parasitic or fungal pathogenic microorganisms that cause dermatitis, or else bacterial genus other than Staphylococcus. Another explanation may justify this result, it was reported in a recent study that not all the preparations could be useful to cure dermatitis. The skin defense is based on the efficacy of the chemical deactivation process through the enzymology mechanisms by broking down the inactive xenobiotics into a more polar inactive metabolite. This is may have place by forming functional groups such as $-\mathrm{OH},-\mathrm{NH} 2$, and -SH [43]. Moreover, in our study, the phytochemical analysis could also give an idea about the plant species effectiveness. It was reported that plants containing high contents of phytochemical compounds such as polyphenols and flavonoids have been considered as useful ingredients in skin cosmetic preparations [44]. Many research groups have explained the effectiveness of total phenols and flavonoids by direct action against germs or through the suppression of microbial virulence factors. For instance, it was reported that flavonoids can inhibit some of the bacterial virulence factors, including quorum-sensing signal receptors, enzymes, and toxins that are necessary for bacteria growth and metabolism [45]. Furthermore, it has been documented that the antibacterial activity of different groups of flavonoids can be attributable to numerous mechanisms such as the inhibition of energy metabolism of bacteria, the inhibition of nucleic acid synthesis, and the inhibition of cytoplasmic membrane function [46]. In the case of the Staphylococcus genus, it was demonstrated that flavonoids have an aggregatory effect on whole bacterial cells [47]. In our study, the active plants were rich in total phenols and total flavonoids which may explain their effectiveness against the target Staphylococcus strains. However, we have demonstrated the antistaphylococcal effect of $B$. hispanica despite the small phytochemical amounts that it contains. Based on an investigation conducted by Musumeci et al. [48], the biological effect of this species could be contributed to the presence of 5'-methoxyhydnocarpine-D and pheophorbide (chlorophyll decomposition products) synthesized by berberine containing in this genus, these substances have no antimicrobial activity, but they are responsible for inhibiting the expression of efflux pumps expression in $S$. aureus through the extruding of antimicrobial agents from bacterial cells [49]. 
Numerous causes may justify the variations of total phenolic and flavonoids contents reported in this work. Indeed, the variation of the polyphenolic content of a plant could be influenced by many biotic factors (Plant species, used part, and physiological stage) and abiotic factors (Environment, solvent) which can affect the metabolism of the plant [50].

Based on all results in the present work, complementary studies are necessary to improve and strengthen these current preliminary findings. This is concern bioassay-guided isolation, purification of the bioactive components, in vivo and toxicity assays. Advanced succeeding scientific research could lead to discover novel and cost-effective drugs against Staphylococcus genus and especially methicillin-resistant strains.

\section{CONCLUSION}

The ethnobotanical study conducted in Fez, Meknes and Taounat cities belonging to Fez-Meknes region in the central North of Morocco documented 55 plant species belonging to 30 families that were traditionally used by the local populations to cure dermatitis.

The 17 most recommended plants were screened for their in vitro antistaphylococcal activity, nine of them found to demonstrate appreciable effects, namely $P$. granatum, $R$. alaternus, $I$. viscosa, O. europea, O. majorana, C. oxyacantha, R. tinctorium, A. herba alba, and $B$. hispanica with MIC values ranging between $0.25 \mathrm{mg} / \mathrm{ml}$ and $16 \mathrm{mg} / \mathrm{ml}$ against MRSA. These plants could be good candidates to overcome infectious diseases associated with Staphylococcus including MRSA infections. Hence, additional deep studies must be maintained such as the search for bioactive fractions and pure compounds that may serve as a potential source of new drugs to treat $S$. aureus, especially MRSA. Furthermore, despite the presence of rich herbal knowledge in the studied region, skin disorders are dermatologic conditions that have a similar clinical appearance, for this reason, much attention must be paid due to the correct diagnosis impacts both the prognosis and the treatment options.

\section{ACKNOWLEDGMENTS}

We are grateful to Professor IBN TATTOU Mohammed from the Scientific Institute in Rabat-Morocco for its help to identify the inventorying plants in this study. We thank also Doctor BALOUIRI Mounyr for his help and his bacterial strains.

\section{AUTHORS' CONTRIBUTIONS}

All the authors have contributed equally.

\section{CONFLICTS OF INTEREST}

The authors declare that they have no conflicts of interest.

\section{REFERENCES}

1. Clarke SR, Foster SJ. Surface adhesins of Staphylococcus aureus. Adv Microb Physiol 2006;51:187-224.

2. Jarvis AW, Lawrence RC. Production of extracellular enzymes and enterotoxins A, B, and C by Staphylococcus aureus. Infect Immun 1971;4:110-5.

3. Gillet Y, Issartel B, Vanhems P, Fournet JC, Lina G, Bes M, et al. Association between Staphylococcus aureus strains carrying gene for panton-valentine leukocidin and highly lethal necrotising pneumonia in young immunocompetent patients. Lancet 2002;359:753-9.

4. Valle J, Vadillo S, Piriz S, Gomez-Lucia E. Toxic shock syndrome toxin 1 (TSST-1) production by staphylococci isolated from goats and presence of specific antibodies to TSST-1 in serum and milk. Appl Environ Microbiol 1991;57:889-91.

5. Tong SY, Davis JS, Eichenberger E, Holland TL, Fowler VG Jr. Staphylococcus aureus infections: Epidemiology, pathophysiology, clinical manifestations, and management. Clin Microbiol Rev 2015;28:603-61.

6. Totté JEE, van Doorn MB, Pasmans SGMA. Successful treatment of chronic Staphylococcus aureus-Related dermatoses with the topical endolysin staphefekt SA.100: A Report of 3 cases. Case Rep Dermatol 2017;9:19-25.

7. Périchon B, Courvalin P. VanA-type vancomycin-resistant Staphylococcus aureus. Antimicrob Agents Chemother 2009;53:4580-7.

8. Isha J, Ashwini H, Pooja R, Radhakrishna M. Nasal colonization of Methicillin-resistant Staphylococcus aureus among clinical postgraduates in a coastal Karnataka medical college prevalence and antibiogram pattern. Asian J Pharm Clin Res 2018;11:104-9.

9. Moran GJ, Krishnadasan A, Gorwitz RJ, Fosheim GE, McDougal LK, Carey RB, et al. Methicillin-resistant S. Aureus infections among patients in the emergency department. N Engl J Med 2006;355:666-74.

10. Newman DJ, Cragg GM. Natural products as sources of new drugs over the 30 years from 1981 to 2010. J Nat Prod 2012;75:311-35.

11. Swarnamoni D, Mukundam B, Shagufa A. Antibacterial activity of the ethanolic extract of leaves of Citrus maxima (burm.) merr. On Escherichia coli and Pseudomonas aeruginosa. Asian J Pharm Clin Res 2013;6:136-9.

12. Badduri N, Gupta NV, Gowda DV, Manohar M. Formulation and development of topical anti acne formulation of spirulina extract. Int J App Pharm 2018;10:229-33.

13. Bikash G, Biswajit D, Sujata P, Aditya B. Preliminary phytochemical screening and in vitro anti-microbial activity of ethanolic extract of Delonix regia (hook) raf. bark (family-Leguminosae). Int J Curr Pharm Res 2018;10:43-6.

14. Moroccan Ministry of the Interior Wilaya of the Region Fez-Meknes, Monograph of the Region Fez-Menkes, Thèses et Mémoires, C28613/14, Thèse No. DL 1987/489; 2016.

15. Kingdom of Morocco: Ministry of Interior. Fez-Meknes Regional Direction, Regional Statistical Directory Fez Meknes, Regional Direction; 2016

16. Agency for the Promotion and Development of the North (APDN). Morocco: The Province of Taounat; 2018.

17. Yeo YL, ChiaYY, Lee CH, Sow HS, Yap WS: Effectiveness of maceration periods with different extraction solvents on in-vitro antimicrobial activity from fruit of Momordica charantia L. J Appl Pharm Sci 2014;4:16-23.

18. Elaloui M, Laamouri A, Ennajah A, Cerny M, Mathieu C, Vilarem G, et al. Phytoconstituents of leaf extracts of Ziziphus jujuba Mill. plants harvested in Tunisia. Ind Crops Prod 2016;83:133-9.

19. Balouiri M, Sadiki M, Ibnsouda SK. Methods for in vitro evaluating antimicrobial activity: A review. J Pharm Anal 2016;6:71-9.

20. Bahorun T, Gressier B, Trotin F, Brunet C, Dine T, Luyckx M, et al. Oxygen species scavenging activity of phenolic extracts from hawthorn fresh plant organs and pharmaceutical preparations. Arzneimittelforschung 1996;46:1086-9.

21. Chaumont JP, Mandin D, Sanda K, Koba K, de Souza CA. Activités antimicrobiennes in vitro de cinq huiles essentielles de Lamiacees togolaises vis-à-vis de germes représentatifs de la microflore cutanée. Acta Bot Gall 2001;148:93-101.

22. Zgórka G, Głowniak K. Variation of free phenolic acids in medicinal plants belonging to the Lamiaceae family. J Pharm Biomed Anal 2001;26:79-87.

23. Btissam R, Fatima EIM, Mohamed N, Fatima EIM, Rubia L. In vitro Study of antibacterial activity of hydro-alcohol morrocan plants extracts. Pharmacogn J 2018;10:519-26.

24. Cocan I, Alexa E, Danciu C, Radulov I, Galuscan A, Obistioiu D, et al. Phytochemical screening and biological activity of Lamiaceae family plant extracts. Exp Ther Med 2018;15:1863-70.

25. Dulla O, Jahan FI. Ethnopharmacological survey on traditional medicinal plants at Kalaroa Upazila, Satkhira district, Khulna division, Bangladesh. J Intercult Ethnopharmacol 2017;6:316-25

26. Azzi R, Rabah D, Farid L, Zohra SF, Houcine B, Nacéra B. Ethnopharmacological survey of medicinal plants used in the traditional treatment of diabetes mellitus in the North Western and South Western Algeria. J Med Plants Res 2012;6:2041-50.

27. Rupani R, Chavez A. Medicinal plants with traditional use: Ethnobotany in the Indian subcontinent. Clin Dermatol 2018;36:306-9.

28. Bouasla A, Bouasla I. Ethnobotanical survey of medicinal plants in Northeastern of Algeria. Phytomedicine 2017;36:68-81.

29. Kolasani A, Xu H, Millikan M. Evaluation of mineral content of Chinese medicinal herbs used to improve kidney function with chemometrics. Food Chem 2011;127:1465-71

30. Al-Qura'n S. Ethnopharmacological survey of wild medicinal plants in Showbak, Jordan. J Ethnopharmacol 2009;123:45-50.

31. Aribi I, Chemat S, Hamdi-Pacha $\mathrm{Y}$, Luyten W. Isolation of berberine tannate using a chromatography activity-guided fractionation from root 
bark of Berberis hispanica Boiss. and Reut. J Liq Chromatogr Relat Technol 2017;40:894-9.

32. Stelmakiene A, Ramanauskiene K, Petrikaite V, Jakstas V, Briedis V. Application of dry hawthorn (Crataegus oxyacantha 1 .) extract in natural topical formulations. Acta Pol Pharm 2016;73:955-65.

33. Burke-Colvin D, Hines M, Gan D. Skin Care Formulations. Justia Patents Number 9833642 United States; 2017.

34. Pacheco-Palencia LA, Noratto G, Hingorani L, Talcott ST, MertensTalcott SU. Protective effects of standardized pomegranate (Punica granatum L.) polyphenolic extract in ultraviolet-irradiated human skin fibroblasts. J Agric Food Chem 2008;56:8434-41.

35. Moorthy K, Punitha T, Vinodhini R, Sureshkumar BT, Vijayalakshmi P, Thajuddin N: Antimicrobial activity and qualitative phytochemical analysis of Punica granatum Linn. (PERICARP). J Med Plants Res 2013;7:474-9.

36. Park HM, Moon E, Kim AJ, Kim MH, Lee S, Lee JB, et al. Extract of Punica granatum inhibits skin photoaging induced by UVB irradiation. Int J Dermatol 2010;49:276-82.

37. Ammar RB, Sghaier MB, Boubaker J, Bhouri W, Naffeti A, Skandrani I, et al. Antioxidant activity and inhibition of aflatoxin B1-, nifuroxazide-, and sodium azide-induced mutagenicity by extracts from Rhamnus alaternus L. Chem Biol Interact 2008;174:1-0.

38. Rhimi W, Salem IB, Immediato D, Saidi M, Boulila A, Cafarchia C, et al. Chemical composition, antibacterial and antifungal activities of crude Dittrichia viscosa (L.) greuter leaf extracts. Molecules 2017;22:E942.

39. Sudjana AN, D’Orazio C, Ryan V, Rasool N, Ng J, Islam N, et al. Antimicrobial activity of commercial Olea europaea (olive) leaf extract. Int J Antimicrob Agents 2009;33:461-3.

40. Leeja L, Thoppil JE. Antimicrobial activity of methanol extract of Origanum majorana L. (Sweet marjoram). J Environ Biol 2007;28:145-6.

41. Abachi S, Khademi F, Fatemi H, Malekzadeh F. Study of antimicrobial activity of selected Iranian plant extracts on vancomycin resistant Staphylococcus epidermidis. J Dent Med Sci 2013;4:59-63.

42. Yashphe J, Segal R, Breuer A, Erdreich-Naftali G. Antibacterial activity of artemisia herba-alba. J Pharm Sci 1979;68:924-5.

43. Dlova NC, Ollengo MA. Traditional and ethnobotanic dermatology practices in Africa. Clin Dermatol 2018;36:353-63.

44. Draelos ZD. Updates in medical skin care. Adv Cosmet Surg 2018;1:211-7.

45. Cushnie TP, Lamb AJ. Recent advances in understanding the antibacterial properties of flavonoids. Int $\mathrm{J}$ Antimicrob Agents 2011;38:99-107.

46. Cushnie TP, Lamb AJ. Antimicrobial activity of flavonoids. Int J Antimicrob Agents 2005;26:343-56.

47. Cushnie TP, Hamilton VE, Chapman DG, Taylor PW, Lamb AJ. Aggregation of Staphylococcus aureus following treatment with the antibacterial flavonol galangin. J Appl Microbiol 2007;103:1562-7.

48. Musumeci R, Speciale A, Costanzo R, Annino A, Ragusa S, Rapisarda A, et al. Berberis aetnensis C. Presl. Extracts: Antimicrobial properties and interaction with ciprofloxacin. Int J Antimicrob Agents 2003;22:48-53.

49. Stapleton PD, Shah S, Ehlert K, Hara Y, Taylor PW. The beta-lactamresistance modifier (-)-epicatechin gallate alters the architecture of the cell wall of Staphylococcus aureus. Microbiology 2007;153:2093-103.

50. Orhan DD, Hartevioğlu A, Küpeli E, Yesilada E. In vivo antiinflammatory and antinociceptive activity of the crude extract and fractions from Rosa canina L. Fruits. J Ethnopharmacol 2007;112:394-400 